\title{
Mitigation of Covid-19 Outbreak in Indonesian Poetry
}

\author{
Mohammad FikriZulfikar ${ }^{1 *}$, Djoko Saryono ${ }^{2}$, Mochammad Syahri $^{3}$ \\ \{fikrizulfikar.1802116@students.um.ac.id ${ }^{1}$ \}
}

Faculty of Letters, State University of Malang, Indonesia ${ }^{1,2,3}$

\begin{abstract}
This research aims to describe knowledge form of outbreak disaster mitigation in Indonesian poetry. This research uses a descriptive qualitative approach through phenomenological hermeneutics of Paul Ricoeur as a meaning interpreter. Epidemiological study is used because the objectives of investigating outbreak among society is to control and prevent the recurrence of the outbreak. The Michel Foucault's archaeological study of knowledge is also used as an instrument to reveal knowledge in poetry. It is used because the language in poetry becomes an instrument for articulating power when the power itself has to take the knowledge form. The reason is because the knowledge is defined in the form of the construction of discursus statements, including discursus about covid-19 outbreak mitigation constructed in Indonesian poetry as knowledge. The data of this research are couplets, typography, diction, images, and concrete word related to the mitigation efforts of covid-19 outbreak disaster found in poetry. The source of this research is 50 poetry by 50 Indonesian authors themed around Covid-19 and published in national newspapers, online media, and poetry anthology bookpublished since January to August 2020. The results of this research shows four types of outbreak mitigation knowledge in poetry, namely agent source control, cutting a link in the chain of transmission, host power-increase, and primordial prevention.
\end{abstract}

Keywords: Outbreak mitigation, covid-19, Indonesian poetry, construction of knewledge, the archaeology of knowledge

\section{Introduction}

During the current Covid-19 outbreak, the governmenta round the world began to focus on health policies, as well as the scientists' research focuses on how to handle the Covid-19 [1]. The global impact which affects human life during this Covid-19 outbreak also becomes a concern to poets in Indonesia. Recorded from January to August 2020, there were many poems which depicted the Covid-19 outbreak situation published in mass media such as newspapers, online media, and anthologies.

The Covid-19 outbreak inspired Indonesian poets in producing their poems. This can be seen in the work of new to senior poets who are quite famous in Indonesia, such as Sutardji Calzoum Bachri who wrote a poem entitled Satu (One), Mustofa Bisri or Gus Mus with his poem entitled Sabda Bumi (Word of Earth), Triyanto Triwikromo with his poem entitled Harus Ditafsirkan Sebagai Apakah Maut (As What Death Should be Interpreted), and Putu Fajar Arcana with his poem entitled Nyanyian Cinta Orang-Orang Pulang (Love Song of The One Coming Home) compiled in a book entitled Peradaban Baru Corona (A New Corona Civilization) [2]. Not only books, some poems about Covid-19 are a lso often found in online media such as those compiled in cakradunia.co written by Denny JA [3] entitled Tanggung 
Jawab Sang Pemula (The Beginner's Responsibility), and Mihar Harahap [4] entitled Covid, Ada Apa Denganmu (Covid, What's Wrong With You)

Real-life depictions are seen in Indonesian poems written during the Covid-19 outbreak. The poems commonly tell about how the societies mitigate this deadly pandemic like doing some efforts to survive by keeping physical distancing and spraying disinfectants. Some works also often highlight the humans' relationship during the pandemic in which they cannot meet face-to-face and it causes somehumanity issues faced by the characters. Several humanity issues due to Covid-19 a ppear in Gus Mus's poem entitled Sabda Bumi (Word of Earth).

The poem entitled Sabda Bumi(Word of Earth) explains the rela tionship between natural conditions a nd the deeds of mankind. It means that the impacts of the Covid-19 outbreak which has devastated the economic and health sectors a re a natural warning so that people a s khalifah (Arabic: human as the leader on earth) are not busy damaging na ture for the sake of earthly pleasures. This pandemic brings impacts that requires people to stay at home to prevent the spread of the virus. The condition of this outbreak seems to suggest humans to take care of the earth by blessing all creatures of Allah. By doing so, disa sters can be solved because the world runs in a balanced way between humans and the environment.

Besides completely entertaining, literary works can also be used to teach something using entertainment system through the authors' thought and diction they created [5]. By reading pandemic-themed Indonesian poems, the readers are indirectly taught something about the concept of knowledge displayed in the narration told in the verses of poems. During the outbreak, poems are expected to teach something to the readers through the discourse constructed by the writers. Some of the built discourse are about controlling and preventing mitigation of the Covid-19 outbreak described in Indonesian poems.

Foucault in his theory of archaeological knowledge states that through discourse, the will to know is arranged in knowledge [6]. Language in poems becomes a tool to articulate power when it has to take the knowledge form because knowledge is arranged in the form of discursive statements construction [7]. Power-knowledge is concentrated in the truth of scientific questions.

Therefore, the writer tries to connect, control, and organize the discourse of the pandemic in order to make it suitable with the scientific demands, so it can be applied by the societies. Okky Madasari [8] explains that Foucault rejected the classification of various discourses (literature, politics, philosophy, religion, history, fiction, and so on). For Foucault, they are all one: a discourse. Thus, in this study, literary works, especially poems that deal with pandemic will be treated as a discourse of knowledge and the facts of the discourseitself.

Literary studies nowadays are highly interdisciplinary, multidisciplinary, and transdisciplinary. This happens because monodisciplinary literary studies in some cases cannot provide comprehensive answers dealing with complex problems of the societies. Literary studies from various perspectives are needed by literary researchers so that they can relate literature with other multidisciplinary knowledge, therefore litera ry research can provide more comprehensive and useful results to the societies [9].

One of the interdisciplinary studies that can be connected to literary studies is epidemiological studies. Reviewing literary works, especially poems using epidemiological studies is expected to be able to reveal the discourse of information on pandemic depicted in Indonesian poems from the process of knowledge construction. Through the epidemiological studies in poems, it is expected that the information in poems can be used as a reference to handle the pandemic. Two of the ways to handle the pandemic is through combat and prevention which is commonly known as mitigation of the Covid-19 outbreak. 
Soemirat [10] explains that in controlling an outbreak, determinant factors can be used in some ways, namely controlling the source of a gents like treating the sufferers, isola ting the sufferers, controlling animal and physical reservoirs, and also detecting the cases actively. Breaking the chain of transmission is also important to control, starting from paying attention to individual hygiene, sterilization, and travel prevention. Moreover, the enhancement of the individual immune system is also important, such as immunization, environmental sanitation, chemical prevention, and a dequate nutrition.

On the other hand, outbreak prevention can be done through four preventive ways, i.e. primordial, primary, secondary, and tertiary prevention [10]. Primordial prevention starts by preventing pollution and maintaining diet, primary prevention is done by preventing the recurrence of the disease and consuming supplement, secondary prevention is done by monitoring periodically and screening massively or gra dually, and tertiary prevention is done by anticipating permanent defects due to the outbreak.

As a part of epidemiological studies, mitiga tion describes human interaction in controlling and preventing the Covid-19 outbreak [11]. Therefore, when the mitigation is a ssociated with literature, epidemiological studies will be used to see the pandemic knowledge written in Indonesian poems. One of the objectives of epidemiological studies that study outbreak among the societies is to control and prevent the recurrence of the outbreak [10]. Thus, the relation or 'matchmaking' between epidemiological studies and literary studies can be called epidemiological literary studies.

There has been no research that offers an epidemiological approach to the outbreak mitigation, especially Covid-19 for the study of literary works, especially Indonesian poems as well as studies using a rchaeological knowledge. Therefore, seeing the tendency of Indonesian poem sublished during the pandemic to reveala lot of knowledge about Covid-19, especially rela ted to the outbreak mitigation. This study aims to find out the construction of knowledge about outbreak mitiga tion found in Indonesian poems.

\section{Method}

This research uses a descriptive qualitative approach through the phenomenological hermeneutics of Paul Ricoeur as an interpreter in understanding meaning. In Hermeneutics, there is an attempt to graft hemeneutics on phenomenology [6]. There are three elements in phenomenological hermeneutics, i.e. first; reflection is understood as a call for a nyone to do an action, second; hermeneutics teaches that there is no self-understanding without being around the signs, symbols and texts, and third; Husserl phenomenology imbued with dreams of knowledge radically characterized by intensionalitas (consciousness is always aware of something and phenomenon which appear to the subject).

Epidemiological and archaeological studies of knowledge are used as instruments in interpreting the text discourse related to covid-19 outbreak mitigation that emphasize the control and prevention of outbreaks that construct knowledge in Indonesian poems. Foucault [12] states that in the documents and monuments including the literary work, history tries to collect traces left by humans in the past. These traces are as scattered knowledge that have to be gathered. From those traces, the Foucault archaeological knowledge was started by collecting the scattered elements, sorting them so that they are relevant to each other, then they are placed in rela tion so there will be a totality. The discursus and the documents produced will be analyzed, described, and organized [13]. 
The results of the descriptive qualitative approach are description data in the form of written or oral words about an observed state or symptom. This a pproach is closely related to the state of the research subjects that appears as it is to make descriptions; images; or systematic, actual, and accurate paintings of the phenomenon of outbreak disaster mitigation forms in Indonesian poems. The data of this research is texts in the form of excerpts of poems which construct the form s of outbreak disaster mitigation. The data source of this research is in the form of poems written by Indonesian poets published in a nthologies and online mass media in January 2020 to August 2020.

\section{Result and Discussion}

The results showed that there are five knowledge constructions of mitigation outbreak in Indonesian poems, i.e. through agent source control, break the chain of transmission, host power increa se, primordial prevention, and tertiary prevention.

\subsection{Agent source control}

The control of the agent source is a n attempt to make patients who are exposed to the disease can be healthy soon and to try to eliminate the symptoms and the virus from the patient's body as well as not to infect the virus to others. In the outbreak disaster mitigation, the agent source control on epidemiological studies tries to control the source of the disease in order to make the patient's body is one hundred percent free from the virus [10]. The agent source control found in Indonesian poems is displayed through character's action in treating the sufferers, isolating the sufferers, and performing physical reservoir control.

Treating the sufferers in mitigation of the Covid-19 outbreak is an effort to prevent the outbreak to make those who are infected with the virus receive medical trea tment to relieve symptoms and for those who had severe pain be referred to the hospital. In Indonesian poems, the treatment of the sufferers is represented in the character's action under the doctor's treatment during the outbreak. The character's a ction under the doctor's treatment found in literary works can be seen in the excerpt of an old poem in the form of pantun (Indonesian verse consisting of four lines rhyming $a b a b$ of which the first two present a figurative suggestion of what is more directly and clearly stated in the final lines) entitled Corona Bisa Sembuh (Corona Can be Cured) by AchmadFachrodji below.

Tembang a smaradana jenis mocopat

Mendengar gambuh sa ngatlah nikmat

Sakit corona memanglah berat

Bisa sembuh tetaplah semangat
(Mocopat type Tembang asmaradana) (Hearing the gambuh is very melodious) (Suffer from corona is indeed hard) (Can be cured keep up the spirit)

The excerpt of the pantun above ex plains that through a n intensive treatment carried out by professional doctors, Covid-19 sufferers can be cured. Thus, the fulfillment of doctors in medical efforts is very important in controlling the Covid-19 outbreak. The Pantun entitled Corona Bisa Sembuh (Corona Can be Cured) constructs epidemiological knowledge about mitigation of Covid-19 outbreak. The outbreak mitigation is carried out by controlling the source of agents by treating the sufferers through healing efforts from doctors and the medics. 
The trea tment from doctors and the medics is important to provide certain therapies as an effort to relieve the sufferer's pain and the virus can be reduced and removed [14].

Isolating the sufferers is also an effort to control the source of agents in mitigation of the Covid-19 outbreak in Indonesian poems. Isolation of Covid-19 sufferers is an effort to separate people infected with the virus from others. In Indonesian poems, the isolation of sufferers is displa yed through the action of character's isola tion done in the hospital. The effort to control the pandemic through isolation in the hospital can be seen in the excerpt of a poem entitled Nyanyian Cinta Orang-Orang Pulang (Love Song of The One Coming Home) by Putu Fajar Arcana as follows.

Can,

ka lau saja kita sempatbertemu

Mungkin a kan kuceritakan saat-saata khirku

Ruang isolasi itu takcukup buat menampung

kerinduanku yang dalam kepada anak-anak,
(If only we'd met)

(Maybe I'll tell you my last moments)

(That isolation room wasn't enough to accommodate)

(My deep longing for children)

(to all our drea ms of independence)

burung-burung di pohon-pohon tua rumahkita. (the birds in the old trees of our house.)

The excerpt of the poem above describes the character in the poem who suffered from the Covid-19 outbreak who finally had to be isolated in an isolation room in the hospital. It was described as a cramped room that he thought it was not enough to hold back the longing with the family. Isolation is done so that the sufferer does nothave physical contact with others which can cause the transmission of the virus. The poem entitled Nyanyian Cinta Orang-Orang Pulang (Love Song of the OneComing Home) constructs the epidemiological knowledge about Covid19 outbreak mitigation. The outbreak mitigation is carried out by controlling the source of agents by isola ting the sufferers in hospitals. Technically, hospitals with good ventilation and adequate hygiene can a lso be used a s isola tion places to prevent the tran smission of the virus [15].

Physical reservoir control is also an effort to control the source of a gents which is done to minimize human encounters because it is considered that the virus can be transmitted to each other. In Indonesian poems, physical reservoir control is represented in various character's action depicting themitigation of the Covid-19 outbreak, including the efforts to keep physical distancing, convene online press conferences, and implement regulations in the form of prohibitions. Some of the prohibitions are bans on going to mosques, assembling, shaking hands, hugging, making visit of condolence, religious activities, a nd accepting guests. One of the character's actions that describes physical reservoir control is the effort to keep physical distancing seen in the poem entitled Satu(One) by Sutardji Calzoum Bachri as follows.

da ging kita satu arwah kita satu
walau masing jauh
yang tertusuk padamu berdarah padaku
(Our flesh is one our spirit is one) (even though each other is far a way) (The one impales on you bleeds on me)

The excerpt of the poem above explains although one is far away from each other due to keeping phy sical distancing during the Covid-19 outbreak, the soul of the one who is far away from each other still can feel the closeness. Happiness seems to be able to feel both pleasure and pain. The excerpt of the poem entitled Satu(One) above constructs epidemiological knowledge on mitiga tion of Covid-19 outbreak. The outbreak mitigation is carried out by controlling agent sources through physical reservoir control in the form of keeping phy sical distancing. Keeping 
physical distancing is implemented to minimize the transmission of the virus through air. The regula tion of keeping physical distancing has been implemented in every countries to reduce the number of virus reproduction [16].

\subsection{Break the chain of transmission}

Outbreak mitigation done by breaking the chain of transmission in this research is vanious discourse that construct Indonesian poems related to efforts to improve the environment in order to stop the transmission of the virus by minimizing its carrier. Breaking the chain of the transmission is done to improve the quality of the environment so that it does not become a vehicle or a habitat for vectors of disease and to break the transmission of virus [10]. Breaking the chain of transmission in Indonesian poems is displayed in the form of character's a ction in implementing individual hygieneefforts, spraying disinfectant and having sterilization, as well as preventing tra vel. Individual hygiene is an effort to mitigate the outbreak to break the chain of transmission by improving personal hy giene in order to a void viru ses which are attached to the body. In Indonesian poems, individual hygiene is represented in the character's action through washing hands. Washing hands is done during the Covid-19 outbreak to clean up the possibility of germs that are accidentally touched or attached to the hands while doing activities. Wa shing hands is shown in an excerpt of poem entitled Milenial Korona (Millennial Corona) by Akhlis Surya patibelow.

$\begin{array}{ll}\text { sekarang tutup mulutmu } & \text { (Now cover your mouth) } \\ \text { jangan kerumun bersatu } & \text { (Don't be at crowd) } \\ \text { jaga jarak } & \text { (Keep your distance) } \\ \text { cuci tangan } & \text { (wash your hands) } \\ \text { korona tak kenal janji tipu daya } & \text { (Corona knows nopromise of deceit) }\end{array}$

The excerpt above explains that to anticipate the viru sa ttached to the palm of the hands and then accidentally touch the face that can cause the virus to be inhaled through nose or mouth, the ha bit of washing hands is important to do. By washing hands, it is expected that the vinus on the hands can die off and cannot be the cause of transmission. The poem entitled Millennial Korona (Millennial Corona) constructs epidemiological knowledge about mitigation of Covid19 outbreak. Outbreak mitigation is ca rried out by breaking the chain of transmission through individual hygiene in the form of hand washing habits. Although washing hands with soap or hand sanitizer is important, it is a lso important to select hand wa sh product because it can also have an impact to the skin health, especially those made from alcohol which potentially can cause irritation [17].

Disinfection and sterilization are also efforts to break the chain of transmission. Disinfection and sterilization are a lso efforts to maintain cleanliness by killing the virus before it infects humans. The effort that can be done during the Covid-19 outbreak by disinfection and steriliza tion is spra ying rooms as well as certain points that may be exposed to the virus due to human activities using liquid disinfectant. In Indonesian poems, disinfection and sterilization efforts appear in two forms of character's actions, including during the Covid-19 corpses handling and settlements spraying. One of the actions of the character is spra ying settlements seen in the poem entitled Dalam Perang dan Damai (In War and Peace) by Adri Damadji Woko a s follows. 


\author{
Dalam kedamaian \\ di antara yang berjarak sedepa \\ dan masih sempatbercinta. \\ Tetapi menghadapi Corona \\ semua tanpa ampun semata \\ membuatmu berjarakdisinfektan
}

\author{
(In peace) \\ (Among 1 depa in distance) \\ (And still have time to make love) \\ (But facing Corona) \\ (all without forgiveness) \\ (make you just distanced with disinfectants)
}

The excerpt of the poem above explains that in facing the Covid-19, people are ready to keep their distance and spray disinfectant liquid. Spraying disinfectant is done to kill the viruses around humans. This is done so that there is no spread of virus. The poem entitled Dalam Perang dan Damai (In War and Peace) constructs epidemiological knowledge on mitigation of Covid19 outbreak. The outbreak mitigation is done by breaking the chain of transmission through disinfection or sterilization by spra ying disinfectant liquid. The use of disinfectant liquid is important to prevent transmission, especially for the medics in handling Covid-19 corpses. Therefore, the strict technical rules related to security a re important for the safety of the medics as well as the societies [18].

In addition to individual hygiene and disinfection efforts, the efforts to prevent travel are also made to break the chain of transmission. Preventing travel is done by trying to stay at home because we do not know those who have been exposed to the virus and potentially tra nsmit the virus to others. In Indonesian poems, efforts to prevent travel a re presented in seven types of the character's actions, including learn from home, work from home, implement Pembatasan Sosial Berskala Besar (a La rge-Scale SocialRestriction), lockdown, stay at home, homecoming ban, and flight cancellation. One of the efforts to prevent travel is staying at home done by the character appears in the poem entitled Rumah (Home) by Iswadi Pratama below.

$$
\begin{aligned}
& \text { Janganpergiibu, (Don't go mom,) } \\
& \text { perkenankan sepasang kaki rentamu istirahat (Let yourold feet rest) } \\
& \text { di rumah yang takpernahmendengar keluh lelah. (in the house that hears the despair) } \\
& \text { Telah kusiapkan secangkir teh, sepiring penganan, dan (I've prepared a cup of tea, a plate } \\
& \text { of food, and) }
\end{aligned}
$$

The excerpt of the poem above explains that during the Covid-19 outbreak, choosing to stay at home is the best way to a void the transmission of the virus. So, the author is seen in his poem advising his mother to stay at home by prohibiting herfrom going a nywhere so that she will stay healthy and won't get infected with the virus outside the house. The poem entitled Rumah (Home) constructs epidemiological knowledge a bout mitiga tion of Covid-19 outbreak. The mitigation of the outbreak is carried out by breaking the chain of transmission by preventing travel in the form of advice to stay at home. In addition to having to do activities at home, keeping physical distancing has to be implemented to reduce the spread of Covid-19 [19].

\subsection{Increase the host power}

Increasing the host power is an effort in the outbreak mitigation to strengthen the immune system in facing the risk of virus that can potentially attack human's body. In this case, the host power includes the degree of sensitivity, immunity and tolerance to the virus, as well as the nutrition status, knowledge, education, and human behavior in facing the source of the disease 
[10]. In Indonesian poems, increasing the host power is presented in three forms of actions, including the efforts of chemical prevention, protection, and nutrition.

Chemical prevention is an effort to increase the host power through the use of materials containing chemicalcompounds to prevent the spread of the Corona virus toward individuals as well as societies. The chemical prevention is done to kill the a ttached germs and viruses before infecting people due to the fact that by u sing the chemicals, the viruses can die off. In Indonesian poems, the chemical prevention presented in the character's action by using hand sanitizer in their daily lives. The use of handsanitizer can be seen in the excerpt of a poem entitled Taun Corona, Sebuah Cerita (A year of Corona, A Story) by Rida K. Liam si as follows.

Dingin cairan handsanitizer
menerobos jaripadapagi hari

Sengitalkohol di balik masker

Menaksir harapan sebelumpergi

Selamat pagi, masih adakah lagi secangkir kopi? (Good morning, is there another cup of
(The cold liquid of hand sanitizer) (break through the fingers in the morning)

(The odor of alcoholbehind the mask)

(Thinking of hopes before lea ving)

The excerpt of the poem above explains that the prevention of virus transmission is done by the use of chemicals such a alcohol which is contained in hand sanitizer used to be applied on hands. The poem entitled Taun Corona, Sebuah Cerita (A year of Corona, A Story) constructs epidemiological knowledge about covid-19 outbreak mitigation. The outbreak mitigation is done by increasing the host power through chemical prevention by using hand sanitizers. The use of hand sanitizer or chemical a ntiseptic to prevent the tran smission of Covid19 is effective if the use of it is appropriate. Further education is needed by the public in order to be a preventive ways against the spread related to Covid-19[20].

Protection efforts are also represented in Indonesian poems constructed by knowledge to break the chain of Covid-19 transmission. Protection is a human effort dealing with the Covid19 virus by using Alat Pelindung Diri (Personal Protective Equipment) such as using hazmat suit and masks to prevent the virus from attaching to the body so that the virus cannot be inhaled into lungs that can cause transmission. In Indonesian poems, protection is represented in two character's actions displayed in the verses of poems, including the action of wearing hazmat suit and masks. One of the protections is the use of masks appears in the poem entitled Catatan Kecil (Little Notes) by Asril Koto below.

\section{Di 2020, tanpa tanggal dan bulan \\ Ahli wabahitu \\ Menganjurkan kita membisu \\ Mulut dan hidung diperban}

(In 2020, with no date and month)

(The pandemic experts)

(Encourage us to be mute)

(Mouth and nose are bandaged)

The excerpt of the poem above explains that the pandemic experts or epidemiologists have advocated to wear a mask that is used as a mean of covering the mouth and nose. This mask will inhibit the virus from entering the human body, so the Corona virus can be a voided. The poem entitled Catatan Kecil (Little Notes) constructs epidemiological knowledge on mitigation of The Covid-19 outbreak. The outbreak mitiga tion is done by increasing the host power through self protection by wearing masks. The use of masks is important, especially when someone wants to do activities in public places and potentially cause crowds. Due to the importance of 
wearing masks, there are sa nctions implemented in some countries for people who do not wear masks in public places [21].

In addition to chemical prevention and protection, nutrition fulfillment efforts a re also important to increase the host power in the Covid-19 outbreak mitigation. Nutrition fulfillment is an effort to fulfill nutritious food to boost the immune system, so it won't be easily infected with the Covid-19 outbreak. In Indonesian poems, the fulfillment of nutrition is represented in two character's actions, including efforts to fulfill nutritious foods and a $n$ attempt to boost the immune system. One of the efforts to fulfill nutrition is the fulfillment of nutritious food which can be seen in the poem entitled Jaga-jaga (Just in Ca se) karya Arbi Tanjung below.

Air panas, jahe, kunyit, serai
Jaga mulut
Jaga hidung
Jaga tangan
Jaga kaki
Jaga air
Jaga udara
Jaga tanah

(Hot water, ginger, turmeric, lemongrass)

(Keep your mouth)

(Keep your nose)

(Keep your hands)

(Keep your feet)

(Keep the water)

(Keep the air)

(Keep the ground)

The excerpt of the poem above explains to boost the immune system so that it won't be weak during the Covid-19 outbreak. One of several ways to boost the immune system is by consuming nutrition. There is also suggestion which can be seen in the poem to consume nutritious drinks with a mix ture of hot wa ter, ginger, turmeric, and lemongrass to increase the host power during the pandemic. The poem entitled Jaga-jaga (Just in Case) constructs epidemiological knowledge about mitigation of Covid-19 outbreak. The outbreak mitiga tion is done by increasing the host power through ginger and turmeric. During the Covid-19outbreak, the fulfillment food and beverages containing essential nutrition is im portant to do. Therefore, the food supplies and logistic costs for the fulfillment of nutritious food can be done during the pandemic to maintain the im mune system [22].

\subsection{Primordial prevention}

Primordial prevention is an effort done to prevent the Corona virus in the surrounding environment by doing healthy habits such as regular exercise to maintain the sustainability of ecosystem. Primordial prevention is also interpreted as prevention by eliminating the rootcause; in this case, keeping the environment healthy and behaving healthy toward the environment as well as ourselves [10]. The primordial prevention efforts found in Indonesian poems form a pattern of prevention in two ways that are carried out through the character's a ctions such as giving suggestions in poems. The two patterns are environmental pollution prevention and green campaigns.

Preventing environmental pollution in primordial prevention is preventing air, water, and soil pollution, so they won'tbe contaminated with corona virus that can cause the outbreak. This is done to keep the environment healthy and safe from potential outbreak transmission because the transmission of Covid-19 is often carried out through air contaminated with virus. In Indonesian poems, preventing pollution is done to prevent air pollution in societies. The efforts to prevent air pollution are seen in the poem entitled Pelajaran untuk Selalu Cuci Tangan (A Lesson to Always Wash Hands) by Akhmad Sekhu as follows. 
Tak ada lagi udarabersih, yang ada kematianmengancam diam-diam

Ma sa darurat ditetapkan, seluruh warga dunia tak berdaya apa-apa

Sungguh semua aktifitas dibuat lum puh tak a da yang bisa dilakukan

(No more clean air, only the covert death is threatening)

(Emergency period is established, all citizens around the world are powerless)

(All activities are paralyzed there is nothing to do)

The excerpt of the poem above describes that the Covid-19 outbreak has caused the air pollution. Accordingly, if the unhealthy air is inha led by humans, they can be infected with the virus. Pollution prevention is indeed needed especially preventing a ir pollution. The prevention efforts can be done by warning people about the importance of clean and healthy air, so people will stop polluting the air. The poem entitled Pelajaran untuk Selalu Cuci Tangan (ALesson to Always Wash Hands) constructs epidemiological knowledge about covid-19 outbreak mitigation. Mitigation of the outbreaks is carried out by primordial prevention through preventing pollution in the form of warnings of the air pollution hazards. Several studies have shown that certain air pollutants can increase the transmission of corona virus and cause the risk of death. As research conducted in Catalonia Spain which showed that the death caused by Covid-19 in urban industrial a reas is higher than in rural a gricultural zones [23].

Green campaigns are a lso prim ordial prevention efforts in addition to preventing pollution. Green campaign in mitigation of Covid-19 outbreak is a effort to promote energy-efficient living and to use clean environmental technology. This is done to keep the surrounding environment healthy and a void the threat of Covid-19 outbreak. In Indonesian poems, green campaigns are represented in two actions, including warning efforts on humans and recommendations to protect the environment. One of the actions is a warning to humans that appears in a poem entitled Sabda Bumi (Word of Earth) by KH. Ahmad Mustofa Bisri or Gus Mus as follows.

\author{
Barangkalibumitelah lelah \\ oleh ulahkhalifahnya yang berulah \\ Seolah-olah meluapkan keluh-kesah: \\ Istirahatlah, wahai khalifah \\ Brentilahmelelah \\ nafkahtak berkah \\ Berkahi sesama hamba Allah \\ mengurasbukan men gurus bumimu yang semakin parah.
}

(Perhaps the earth is tired)

(by the a ctions of its khalifah)

(As if it complained:)

(Take a break, khalifah)

(Stop feeling tired)

(The unblessed living)

(Bless the other servants of God)

(Depleting is not taking care of your earth which is getting worse.)

The poem above describes that the Covid-19 outbreak has devastated the economic as well as health sectors. It is a natural warning that the people as khalifah on earth are not busy 
da maging nature. Moreover, it is expected that khalifah can take care of the earth by blessing all creatures of God. The poem entitled Sabda Bumi (Word of Earth) constructs epidemiological knowledge about mitigation of Covid-19 outbreak. The outbreak mitigation is carried out by primordial prevention through green campaigns in the form of natural warnings. The Covid-19 outbreak is as a warning for people not to damage the environment, especially the wild. By not ra ising or consuming wild animals, the transmission of the virus can be reduced because it is known at the beginning that the spread of this virus is from bats and pangolin which belong to wild a nimals. So, it is important to do conservation and environmental preservation for mutual benefit [24].

\subsection{Tertiary prevention}

Tertiary prevention is an effort made in the medical field to cure patients so that the disease they suffer from won't get worse that can cause disability and death. This effort aims to prevent defects which widely happened during the treatment and rehabilitation of sufferers, so it won't be related to the expertise of environmental engineering or environmental fields [10]. In Indonesian poems, tertiary prevention appears through the character's action when rehabilitating Covid-19 patients.

Rehabilitation of patients is the fulfillment of health facilities for people who are monitored because they are indicated to be infected with the Covid-19 outbreak. Rehabilitation efforts of these patients are represented through the efforts of the medics in rehabilitating the sufferers. The efforts of the medics are seen in an old poem in the form of pantun entitled Pahlawan Sejati (True Heroes) by Achmad Fachrodjibelow.

\section{Seindah amarilis si bungadahlia \\ Dipadu melati menghiasi istana \\ Tenaga medis sangatlahmulia \\ Pahlawan sejati melawan Corona}

(As bea utiful as a maryllis the dahlia flower)

(Combined with ja smine decorated the palace)

(The medics a re very noble)

(True heroes against Corona)

The excerpt of the pantun above explains the importance of the medics in handling and recovering the Covid-19 patients. In addition to having to fight to cure patients, the medics must also be ready to be infected with the virus becau se they a re susceptible to be infected. Because of their sacrifice, the medics are considered as true heroes because their obliga tion is very noble. Pantun entitled Pahlawan Sejati (True Heroes) constructs epidemiological knowledge about mitigation of Covid-19 outbreak. The outbreak mitigation is carried out by tertiary prevention through rehabilitation of patients done by the medics. To maximize the performance of the medics to prevent Covid-19, the fulfillment of the number and arrangement of working hours of the medics is important. In addition, the completeness of medical equipment and personal protection is a lso a priority for the success of handling patients [25]. 


\section{Conclusion}

As shown in this article, outbreak disaster mitigation is a part of a nepidemiological study that discusses human interaction related to efforts in controlling and preventing a outbreak. Indonesian poems published from the beginning of 2020 to August 2020 show us a lot of knowledge construction about disaster mitigation of the Covid-19 outbreak depicted in the actions of its characters. From the excerpts of poems, there are five types of disaster mitigation of Covid-19 outbreak, i.e. efforts in controlling the source of a gents, breaking the chain of transmission, increasing the host power, implementing primordial prevention, as well as tertiary prevention.

The source of the agent control is constructed by the character's actions in the form of efforts to treat sufferers under the treatment of doctors in Indonesian poems. Besides, the isolation of the sufferers is also done by isolating the sufferers in hospitals. Physical reservoir control is carried out through policies of keeping physical distancing and conducting online press conferences. In addition, policies in the form of prohibitions are also carried out to control the physical reservoirs, including bans on going to mosques, assembling, shaking hands, hu gging, ma king visit of condolence, religious activities, a nd receiving guests.

Moreover, efforts to mitigate the outbreak through breaking the chain of transmission are also constructed in Indonesian poems. Breaking the chain of transmission is done through individual hygiene that is constructed in poems by the habit of washing hands to avoid the Covid-19 virus. Disinfection and sterilization efforts are also seen in Indonesian poems represented in two actions, including the Covid-19 corpses handling and settlements spraying to kill viruses before infecting humans. Preventing tra vel is also an effort to break the chain of transmission by doing several actions i.e. learn from home, work from home, Pembatasan Sosial Berskala Besar (a Large-Scale Social Restriction), lockdown, stay at home, homecoming ban, and flight cancellations.

Efforts to mitigate the outbreak by increasing the host power a re also constructed in Indonesian poems through the character's actions in chemical prevention, protection, and nutrition. Chemical prevention is ca rried out by using handsanitizer, preparing Alat Pelindung Diri (Personal Protective Equipment) such as wearing masks, providing fluids, a nd wearing of hazmat suit for the medics in handling Covid-19 patients. Those efforts can be seen in Indonesian poems. In addition, the fulfillment of nutrition and vitamins is also carried out to increa se the host power by fulfilling nutrition and encouraging people to consume nutritious food to increase the immune system.

Disa ster mitigation is a lso constructed in Indonesian poems through the character's action when trying to implement primordial prevention. The efforts are preventing pollution by preventing air pollution in societies. In addition, green campaign s by recognizing the natural warnings about the causes of an outbreak and campaign for protecting the environment are primordial prevention efforts. In addition, tertiary prevention is also seen in the efforts of rehabilitation of of the sufferers by the actions shown by the medics in handling their pa tients. The construction of outbreak mitigation knowledge in Indonesian poems is expected to be a reminder for readers and the public in order to be a guide in controlling and preventing the transmission of Covid-19 during this pandemic. 


\section{References}

[1] R. Chaudhry, G. Dranitsaris, T. Mubashir, J. Bartoszko, and S. Riazi, "A country level analysis measuring the impact of government actions, country preparedness and socioeconomic factors on COVID-19 mortality and related health outcomes," EClinicalMed icine, vol. 000, p. 100464, 2020, doi: 10.1016/j.eclinm.2020.100464.

[2] S. C. Bachri, M. Bisri, T. Triwikromo, P. F. Arcana, and etc, Peradaban Baru Corona: 99 Puisi Wartawan Penyair Indonesia, 1st ed. Bogor: PT. Anugrah Java Media, 2020.

[3] D. J. Ali, "Puisi-puisi Covid-19 Denny JA," cakradunia.co, 2020. https://cakradunia.co/news/puisipuisi-covid-19-denny-ja/index.html (accessed Aug. 01, 2020).

[4] M. Harahap, "Puisi-puisi Covid-19 Mihar Harahap," cakradunia.co, 2020. https://cakradunia.co/news/puisi-puisi-covid-19-mihar-harahap/index.html (accessed Aug. 01, 2020).

[5] Aristoteles, Puitika: Seni Puisi, 1sted. Yogyakarta: Basabasi, 2017.

[6] Haryatmoko, Membongkar Rezim Kepastian: Pemikiran Kritis Post-Strukturalis. Yogyakarta: PT Kanisius, 2016.

[7] M. Jalal, "Praktik Diskursif The Theory of Truth Michel Foucault dalam Konstruksi Simbolisasi Bahasa di Indonesia," J. Univ. Airlangga, 2007, [Online]. Available: http://journal.unair.ac.id/filerPDF/Praktik Diskursif.pdf.

[8] O. Madasari, Kapitalisme, Islam, Dan Sastra Perlawanan. www.okkymadasari.net, 2019.

[9] S. Y. Sudikan, "Pendekatan Interdisipliner, Multidisipliner, dan Transdisipliner dalam Studi Sastra," Paramasastra, vol. 2 (1), 2015, doi: http://dx.doi.org/10.26740/parama.v2n1.p\%25p.

[10] J. Soemirat, Epidemiologi Lingkungan, 4th ed. Yogyakarta: Gadjah Mada University Press, 2015.

[11] T. Tsou et al., "Epidemiology of the first 100 cases of COVID-19 in Taiwan and its implications on outbreak control,” J. Formos. Med. Assoc., pp. 1-7,2020, doi: 10.1016/j.jfma.2020.07.015.

[12] M. Foucault, Arkeologi Pengetahuan. Yogyakarta: Basabasi, 2019.

[13] G. Ritzer and D. J. Goodman, Teori Sosiologi Modern. Jakarta: Kencana, 2004.

[14] W. Chan, B. He, X. Wang, and M.-L. He, "Pandemic COVID-19: current status and challenges of antiviral therapies," Genes Dis., no. xxxx, 2020, doi: 10.1016/j.gendis.2020.07.001.

[15] A. Kenarkoohi et al., "Hospital indoor air quality monitoring for the detection of SARS-CoV-2 (COVID-19) virus," Sci. Total Environ., vol. 748, p. 141324, 2020, doi: 10.1016/j.scitotenv.2020.141324.

[16] W. C. Koh, L. Naing, and J. Wong, "Estimating the impact of physical distancing measures in containing COVID-19: an empirical analysis," Int. J. Infect. Dis., pp. 1-33, 2020, doi: 10.1016/j.eplepsyres.2019.106192.

[17] C. W. Rundle et al., "Hand Hygiene During COVID-19: Recommendations from the American Contact Dermatitis Society," J. Am. Acad. Dermatol., 2020, doi: 10.1016/j.jaad.2020.07.057.

[18] M. Achak, S. B. Alaoui, Y. Chhiti, F. E. M'hamdi Alaoui, N. Barka, and W. Boumya, "SARS-CoV2 in hospital wastewater during outbreak of COVID-19: A review on detection, survival and disinfection technologies," Sci. Total Environ., no. xxxx, p. 143192, 2020, doi: 10.1016/j.scitotenv.2020.143192.

[19] N. Cahyati and R. Kusumah, "Peran Orang Tua Dalam Menerapkan Pembelajaran Di Rumah Saat Pandemi Covid 19," J. Golden Age, vol. 4, no. 1, pp. 152-159, 2020.

[20] A. L. Larasati, D. Gozali, and C. Haribowo, "Penggunaan Desinfektan dan Antiseptik Pada Pencegahan Penularan Covid-19 di Masyarakat,” Maj. Farmasetika, vol. 5, no. 3, pp. 137-145, 2020, doi: 10.24198/mfarmasetika.v5i3.27066.

[21] E. K. J. Dzisi and O. A. Dei, "Adherence to social distancing and wearing of masks within public transportation during the COVID 19 pandemic,” Transp. Res. Interdiscip. Perspect., vol. 7, p. 100191, 2020, doi: 10.1016/j.trip.2020.100191.

[22] T. Perdana, D. Chaerani, A. L. H. Achmad, and F. R. Hermiatin, "Scenarios for handling the impact of COVID-19 based on food supply network through regional food hubs under uncertainty," Heliyon, vol. 6, no. 10, p. e05128, 2020, doi: 10.1016/j.heliyon.2020.e05128. 
[23] M. Marquès, J. Rovira, M. Nadal, and J. L. Domingo, "Effects of air pollution on the potential transmission and mortality of COVID-19: A preliminary case-study in Tarragona Province (Catalonia, Spain)," Environ. Res., vol. 192, no. October 2020, 2020, doi: 10.1016/j.envres.2020.110315.

[24] F. Mubarok and J. Fajar, "Pandemi COVID-19, Peringatan untuk Manusia Hidup Berdampingan dengan Satwa Liar," mongabay.co.id, 2020. https://www.mongabay.co.id/2020/03/14/pandemicovid-19-peringatan-untuk-manusia-hidup-berdampingan-dengan-satwa-liar/ (accessed Nov. 24, 2020).

[25] J. G. Rizal, "Satgas Covid-19 IDI: Kondisi Sekarang Lebih Berat untuk Tenaga Kesehatan," kompas.com, 2020. https://www.kompas.com/tren/read/2020/08/13/124707765/satgas -covid-19idi-kondisi-sekarang-lebih-berat-untuk-tenaga-kesehatan?page=all (accessed Nov. 24, 2020). 